\title{
Screening, brief intervention, and referral to treatment for risky stimulant use in a Skid Row community health center
}

\author{
Lillian Gelberg ${ }^{1 *}$, Ronald M Andersen', Lisa Arangua ${ }^{2}$, Henry Teaford ${ }^{2}$, Niree Hindoyan², Sareen Malikian², \\ Jose C Muniz Castro², Hugo Yepez ${ }^{2}$, Mani Vahidi \\ From International Network on Brief Interventions for Alcohol Problems (INEBRIA) Meeting 2011 \\ Boston, MA, USA. 21-23 September 2011
}

The University of California at Los Angeles Quit Using Drugs Intervention Trial (QUIT) aims to conduct a randomized controlled trial of a primary-care based very brief intervention protocol for reducing risky stimulant use and drug-related harm in low-income, racially diverse primary care patients attending safety-net clinics in the east central Skid Row area of Los Angeles. The QUIT trial emphasizes screening, very brief clinician advice (2-3 minutes), and two telephone drug-use health education sessions versus usual-care in the control group (240 patients per condition). Between February 18 and April 28, 2011, pre-visit screening of adults in the waiting room was conducted using a touch-screen Tablet PC. "At risk" drug use was defined as casual, frequent, or binge use without the physiological or psychological manifestations of dependence (a score of 4 to 26 on the World Health Organization's Alcohol, Smoking, and Substance Involvement Screening Test (ASSIST). A total of 920 adult patients were approached: $89 \%$ were $40+$ years old; $68 \%$ were male; $62 \%$ were black, $21 \%$ were Latino, and $17 \%$ were white. Of patients approached, 706 were excluded due to pregnancy, because it was a nonprimary care visit, or because they refused to participate. Among the 214 who completed the ASSIST, substance use scores were none or low risk in $11 \%$ of participants, moderate risk in $42 \%$, and dependence-level in $47 \%$. The number of participants in each score range by substance were, respectively, tobacco 55 , 101, and 58; alcohol 62, 98, and 54; cannabis 94, 77, and 43 ; cocaine 89,74 , and 51 ; methamphetamine/amphetamine type stimulants 145,45 , and 23 ; inhalants 185,20 , and 9; sedatives 143, 45, and 26; hallucinogens 174, 30,

'University of California/Los Angeles Center for Health Policy Research, Los Angeles, CA, USA

Full list of author information is available at the end of the article and 10; and opioids 130, 54, and 30. Participants who were older than 50 years were more likely to use tobacco, alcohol, cannabis, and cocaine; younger patients were more likely to use amphetamines, inhalants, sedatives, hallucinogens, and opioids. Twenty-seven patients (3\% of those approached) met study criteria of past three-month risky stimulant use. Seventy percent were homeless, and 30\% were marginally housed. In Skid Row, only 3\% of patients qualified for risky stimulant use intervention.

\section{Author details}

'University of California/Los Angeles Center for Health Policy Research, Los Angeles, CA, USA. ${ }^{2}$ David Geffen School of Medicine, University of California/ Los Angeles, CA, USA.

Published: 9 October 2012

doi:10.1186/1940-0640-7-S1-A11

Cite this article as: Gelberg et al.: Screening, brief intervention, and referral to treatment for risky stimulant use in a Skid Row community health center. Addiction Science \& Clinical Practice 2012 7(Suppl 1):A11.

Submit your next manuscript to BioMed Central and take full advantage of:

- Convenient online submission

- Thorough peer review

- No space constraints or color figure charges

- Immediate publication on acceptance

- Inclusion in PubMed, CAS, Scopus and Google Scholar

- Research which is freely available for redistribution

Submit your manuscript at www.biomedcentral.com/submit
C Biomed Central

C 2012 Gelberg et al; licensee BioMed Central Ltd. This is an Open Access article distributed under the terms of the Creative Commons Attribution License (http://creativecommons.org/licenses/by/2.0), which permits unrestricted use, distribution, and reproduction in any medium, provided the original work is properly cited. 